\title{
Empowerment of Relocation Community Affected by Covid 19 Pandemic in DKI Jakarta with Collaborative Governance
}

\author{
Mawar ${ }^{1}$, Soesilo Zauhar ${ }^{2}$, Endah Setyowati ${ }^{3}$, \\ Suryadi ${ }^{4}$, Dini Gandini P5 $^{5}$ \\ ${ }^{1}$ Faculty of Administrative Sciences, Brawijaya University (email: Mawarhidayat22@gmail.com) \\ 22Faculty of Administrative Sciences, Brawijaya University (email: soesilozfia@ub.ac.id) \\ ${ }^{3}$ Faculty of Administrative Sciences, Brawijaya University (email: endah_s-fia@ub.ac.id) \\ ${ }^{4}$ Faculty of Administrative Sciences, Brawijaya University (email: Suryadiub@gmail.com) \\ ${ }^{5}$ Faculty of Social and Political Sciences, University Muhammadiyah Jakarta \\ (email: Purbaningrum_dg@ymail.com)
}

\begin{abstract}
The covid-19 pandemic that has hit the world and Indonesia in particular is not only about the number of people exposd to the virus, but its impact on the economic life of society and the country. The slowdown in various economic activities, the business world, trade and various elements driving the real economy have led to a potential decline in the per capita income of the Indonesian population. This is what is felt by the people of the suburbs at the Rawabebek rusunawa DKI Jakarta who really depend on micro-enterprises for their living. They have experienced a decrease in income since the COVID-19 pandemic so they have limitations in meeting the needs of daily life. For this reason, sustainable community empowerment efforts are needed through aapproach Collaborative Governance. The purpose of this study is to analyze empowerment programs that have been carried out for communities affected by the COVID-19 pandemic through collaborative governance. This study uses a qualitative approach to the type of phenomenological research. The results showed that the collaboration process in empowering the relocation community at the Rawabebek flats only touched on the instrumental aspects and had not touched the substantial aspects. The collaborative process in empowering relocation communities should be based on social capital.capital Socialis capital that can be used as the driving force in empowerment. Social capital provides support to the community to take action together and reciprocally. Social capital is an alternative form of modality that is beneficial for the community to obtain both economic and social benefits.
\end{abstract}

\section{Keywords:}

empowerment; collaborative governance; pandemic covid 19

\section{Introduction}

Since Indonesia first confirmed cases of Covid-19 on March 2, 2020, the number of 
people exposed to the virus continues to increase day by day. If the previous epicenter was centered in Jakarta and its surroundings, now cases of COVID-19 infection continue to spread to other areas and have become a new epicenter. The COVID-19 outbreak is not only a matter of the number of people exposed, but its impact on the economic life of the community and the state, namely unemployment and poverty.

The impact of the Covid-19 disease is a problem that has a systemic impact. Efforts to reduce human movement to prevent contact so that it is expected to suppress the spread of the virus that causes Covid-19 throughpolicies, it turns out Social Distancing and Physical Distancing that these efforts also require regulation in various sectors such as business, trade, tourism, transportation, religious activities and so on.

Several policies were issued by the government as an effort to break the chain of transmission of the COVID-19 outbreak, namely the President simultaneously issued 3 policies related to the handling of the Covid-19 outbreak, namely Presidential Decree Number 11 of 2020 concerning the Determination of Public Health Emergency Corona Virus Diseases 2019 (Covid 19), then Government Regulation (PP) Number 21 of 2020 concerning Large-Scale Social Restrictions in the Context of Accelerating the Handling of Corona Virus Diseases 2019 (Covid 19) and finally Government Regulation in Lieu of Law (Perpu) Number 1 of 2020 concerning State Financial Policy and Financial Stability for Handling The 2019 Corona Virus Diseases (Covid-19) pandemic in order to face threats that endanger the national economy and or financial system stability. However, the above policy turned out to be disharmony. The government's policy disharmony had a very severe impact on economic activity (IMF, 2020). The COVID-19 pandemic has led to an increase in the situation of uncertainty in people's economic activities (Baker et al., 2020).

The implementation of the policy to impose restrictions on community activities (PPKM), especially in DKI Jakarta, turned out to be less effective because the community felt that they had not fully received legal protection for the existing policies made by the current government. The government has not been able to guarantee and ensure, especially for the lower middle class to be able to meet their needs (Ristyawati, 2020). The longer the implementation of the PPKM policy, the income of micro, small and medium enterprises (MSMEs) will decrease (Soemari et al., 2020). While the results of research conducted by (Aduhene \& Osei-Assibey, 2021) that Ghana can turn the disaster caused by the COVID-19 
pandemic into prospects and opportunities by investing heavily in the health sector and creating support for SMEs that create jobs. massively. The increasing pandemic affects social interactions and economic activities through social distancing policies that are enforced which have different levels of strictness in each region. Social policies can affect the social and economic welfare of citizens (Ozili, 2020).

The slowdown in various economic activities, the business world, trade and various elements driving the real economy have caused a decline in the per capita income of the Indonesian population. The direct impact is a decrease in purchasing power and an increase in the number of people who are below the poverty line standard. The decline in people's purchasing power will affect the circulation of money in the market, thereby further suppressing the slowdown in trading activity which in turn has a systemic impact on the economic sector.

The impact of the COVID-19 pandemic on the economic sector has been felt immensely for the people of suburban areas in the capital city of Jakarta, who rely heavily on micro-enterprises for their livelihood. This is what happened to the relocation community living in the Rawabebek flats in DKI Jakarta. Their lives were previously still able to access economic resources when they were still domiciled in their area of origin (Bukit Duri and North Penjaringan), but the impact of the PPKM policy resulted in the community experiencing limited access because the location of their residence in the Rawabebek flat in East Jakarta was very far from the location. Their work is located in the area of origin, namely Bukit Duri (South Jakarta), Krukut River (Central Jakarta) and North Penjaringan (North Jakarta). The relocation community, most of whom (80\%) work in the informal sector and depend on micro-enterprises, have experienced a decline in income since the COVID-19 pandemic with the PPKM policy.

Based on the foregoing, residents who have difficulties in developing their lives and overcoming economic difficulties, need to be provided with economic and social assistance through empowerment. Their livelihoods are casual laborers, motorcycle taxi drivers, forklift workers and fishermen. Their education is low. They find it difficult to develop a business in a new place to increase family income, even though the necessities of life are many. Intense service is needed by providing various assistance and empowerment. Community empowerment requires sustainable efforts. To empower the community, especially those 
relocating to the Rawabebek flats in Jakarta, aapproach is needed Collaborative Governance. Collaborative Governance as an activity and structure in making public policy decisions and management with the involvement of individuals who constructively pass through the barriers of government institutions, private groups and civil society in carrying out public interests that cannot be achieved without involving the private sector and civil society groups. (Emerson et al., 2012).

So far, the management of the Rusunawa is fully run by the government. The concept of governance itself emphasizes the implementation of the governing function jointly by the government and other institutions, such as the private sector, non-governmental organizations and academia. Although governance implies a reduction in the role of government, the government as an institution cannot be left alone. Reform of the administration of public services and development should be more directed at efforts to build governance rather than government. Governance as emphasized refers more to a new method by which society is governed (a new method of community participation in government (Rhodes, 1996) . The government is required to be able to interact harmoniously with the power of society (civil society) and the private sector (private sector) as a consequence from governanceEfforts to empower the community, especially the relocation community at the Rawabebek Rusunawa DKI Jakarta, must be carried out through increased participation and a collaborative approach.

This study analyzes the collaboration process in empowering the relocation community of Rawabebek flats affected by the COVID-19 pandemic, because so far the implementation of collaboration has been in empowering the residents of the flats still shows the dominance of the government's role by using very minimal budget and funds. The government plays a central position both in planning and implementing community empowerment programs, so it has not shown good results. This empirical phenomenon as supported by research results (Larruina et al., 2019) which state that the government plays an important role in creating a collaborative process. On the other hand, research results (Ntale et al., 2020) state that the hierarchical organizational structure in government hinders the collaboration process because it shows a relational, interactional, inclusive and less democratic space among stakeholders.

One of the inhibiting factors in community empowerment is program unpreparedness 
( Citra, 2018) The results of research conducted by (sonderskov, 2019) show the findings that failure in collaborative governance is caused by many obstacles to the authority of the organizational hierarchy, low government commitment, low public trust, limited human resources $(H R)$, limited information, lack of involvement of other stakeholders such as local government capacity. Furthermore, research conducted by (Enciso-Santocildes et al., 2020) shows almost the same results, namely an effective collaboration process based on trust, active stakeholder participation, solidarity and commitment. However, the findings from the research (Frankowski, 2019) show different results, namely the collaborative strategy implemented sometimes contradicts the values of Collaborative Governance itself, thus requiring initial negotiations. The results of the study (Diaz-Delgado et al., 2020) show that human resources (HR) are a very fundamental factor in the collaboration process, therefore training and strengthening of competencies and skills are needed so that HR can produce innovations in the collaboration process. Furthermore, according to research results (Muntonyi et al., 2020) that leadership empowerment has a significant effect on individual innovation. Research findings (Eweje et al., 2021) show that the community does not have a dominant position in the collaborative process of public policy formulation, but the phenomenon of relocating communities in Rawabebek rusunawa shows that the community has a dominant position in the collaboration process. This can be seen from the information submitted by the residents of the flats that the empowerment program carried out by UPRS, collaboration with MSMEs and community NGOs is not fully involved in the formulation of empowerment programs. (results of interviews with residents of the flats, February 2021) . On the other hand, the collaboration process requires sharing between the implementer and the target group so that the real needs and problems of the community can be identified in real terms.

In an effort to empower the community, it can be seen from three sides, namely (Huraerah, 2011) : first, creating an atmosphere or climate that allows the potential of the community to develop (enabling). Second, strengthening the potential of the community through concrete steps involving the provision of various inputs and opening up opportunities that will make the community more empowered. Third, protect and defend the interests of the weak. To increase public participation in decision-making processes involving themselves and their communities is an important element, so that community empowerment 
is closely related to the consolidation, civilization and experience of democracy. What needs to be encouraged in the collaboration process in empowerment programs is the active participation of the community because this will determine the success of the collaboration process (Uddin, 2019). The concept of partnership (collaboration) is very important to realize sustainable development (Eweje et al., 2021) and the collaboration process is the main driving factor in overcoming the economic crisis. Cross-sectoral collaboration process based on trust, institutions, active stakeholder participation, solidarity and commitment (Enciso-Santocildes et al., 2020)

\section{Methods}

This research uses a qualitative approach with a phenomenological type of research. The qualitative approach was chosen because of its ability to gain a deep, authentic, and basic understanding of the phenomenon ofcommunities relocationaffected by the COVID-19 pandemic. Data collection techniques are through interviews, observation and documentation.

\section{Results and Discussion}

The impact of the COVID-19 pandemic on the economic sector has been greatly felt for the people of suburban areas in the capital city of Jakarta, who rely heavily on microenterprises for their livelihood. This is what happened to the relocation community living in the Rawabebek flats in DKI Jakarta. Their lives were previously still able to access economic resources when they were still domiciled in their area of origin (Bukit Duri and North Penjaringan), but the impact of the PPKM policy resulted in the community experiencing limited access because the location of their residence in the Rawabebek flat in East Jakarta was very far from the location. Their work is located in the area of origin, namely Bukit Duri (South Jakarta), Krukut River (Central Jakarta) and North Penjaringan (North Jakarta). The relocation community, most of whom $(80 \%)$ work in the informal sector and depend on micro-enterprises, have experienced a decline in income since the COVID-19 pandemic with the PPKM policy.

Currently, there are thousands of evictees who inhabit rusunawa Rawabebek that berlokasi in East Jakarta. They come from various areas, such as: Kampung Aquarium 
(Penjaringan, North Jakarta), the banks of Krukut River (Central Jakarta) and Bukit Duri (Tebet, South Jakarta). The Rawa Bebek Rusunawa Complex is divided into 14 blocks. "So, in total There are only 1,150 residential units here, meanwhile, the remaining 400 units are still under construction and is targeted for completion by the end of 2020," he said Administrator of the Rawa Duck Flat Service Unit (UPRS), Dwi Marsanto.

The people who live in the flats currently number 700 families with a total ofresidents 4587 people consisting of :

Table 1.

Number of Family Heads of Relocation Community Rusunawa Rawabebek

\begin{tabular}{clcc}
\hline No. & \multicolumn{1}{c}{ Area of Origin } & Number of KK & Group Community \\
\hline 1. & Bukit Duri (Jakarta Selatan) & 593 & Relokasi \\
2. & Cawang (Jakarta Timur) & 22 & Umum \\
3. & Kali Krukut (Jakarta Pusat) & 22 & Relokasi \\
4. & Penjaringan Utara (Jakarta Utara) & 163 & Relokasi \\
\hline
\end{tabular}

Source: Management Unit Rusunawa Rawabebek (2020)

Table 2.

Number of General Public and Residents Relocating Rusunawa In DKI Jakarta Province

\begin{tabular}{clcc}
\hline No. & \multicolumn{1}{c}{ Rusunawa } & $\begin{array}{c}\text { Amount } \\
\text { Public General }\end{array}$ & $\begin{array}{c}\text { Quantity } \\
\text { Reallocation Society }\end{array}$ \\
\hline 1. & Cakung Barat & $41.86 \%$ & $58.14 \%$ \\
2. & Cipinang Besar Selatan & $22.08 \%$ & $77.92 \%$ \\
3. & Daan Mogot & $3.44 \%$ & 96.56 \\
4. & AWestern atinegara & $92.21 \%$ & $7.79 \%$ \\
5. & NationalIdentity of the & $20.43 \%$ & $79.57 \%$ \\
6. & People & & \\
7. & Netirawasari Coral & $6.90 \%$ & $93.1 \%$ \\
8. & Kamaruddin & $55 \%$ & $45 \%$ \\
9. & Marunda & $60.53 \%$ & $39.47 \%$ \\
10. & Muara Baru & $6.56 \%$ & $93,44 \%$ \\
11. & Networking & $5.67 \%$ & $94.33 \%$ \\
\hline
\end{tabular}




\begin{tabular}{clcc}
\hline 12. & Beautiful Pine & $4.04 \%$ & $95.96 \%$ \\
13. & Bamboo Hut & $100 \%$ & $0 \%$ \\
14. & Gebang Island & $33.3 \%$ & $66.7 \%$ \\
15. & Pulo Ginger & $88.89 \%$ & $11.11 \%$ \\
16. & Rawabebek & $3.14 \%$ & $96.86 \%$ \\
17. & Tambora & $15.57 \%$ & $84.43 \%$ \\
18. & Tipar Cakung & $80.61 \%$ & $19.39 \%$ \\
19. & Cipinang Besar Utara & $100 \%$ & $0 \%$ \\
20. & Cipinang Muara & $100 \%$ & $0 \%$ \\
21. & Semper & $100 \%$ & $0 \%$ \\
22. & Kapok Muara & $100 \%$ & $0 \%$ \\
\hline
\end{tabular}

Data Source: DKI Jakarta Public Housing and Residential Areas Office, 2020

Seen in table 2. above the relocation community, the largest number is in rusunawa Rawabebek which amounted to about $96.86 \%$, while the general public only berjumlah $3.14 \%$. The conditions of the flats are more comfortable than their homes, not immediately makes residents live comfortably in the flats during the current covid 19 pandemic. A number of problems arise precisely when they relocated to the area, ranging from jauh from relatives and workplace, loss of livelihood, arrears of rent, to the practice of buying and selling flat units. Most of the residents who used to sell at their residence they were forced to lose their livelihood. They admit that it is difficult to get income in the flats to meet daily needs. There are residents who complained about how far the flats were from where they worked. They have to wake up and leave for work earlier than usual because since the transportation mode pandemic limited due to the implementation of the PPKM policy. It has fallen down the stairs too. That is the term analogous to some people who live in the Rawabebek flats in DKI Jakarta. Although the flats they live in look luxurious, nice and clean, their economic life is very concerning.

Table 3.

Average Income of Residents of Rusunawa in DKI Jakarta Province

\begin{tabular}{ccc}
\hline No. & Rusunawa & Average Income of Occupants (Rp) \\
\hline 1. & Cakung Barat & 5.363 .000 \\
\hline
\end{tabular}




\begin{tabular}{clc}
\hline No. & \multicolumn{1}{c}{ Rusunawa } & Average Income of Occupants $($ R $\boldsymbol{p})$ \\
\hline 2. & Cipinang Besar Selatan & 3.861 .000 \\
3. & Daan Mogot & 5.665 .000 \\
4. & Jatinegara Barat & 3.935 .000 \\
5. & Jatinegara Kaum & 3.266 .000 \\
6. & Jatirawasari & 4.566 .000 \\
7. & Karang Anyar & 4.166 .000 \\
8. & Kamaruddin & 4.017 .000 \\
9. & Marunda & 3.803 .636 \\
10. & Muara Baru & 5.089 .000 \\
11. & Penjaringan & 5.561 .000 \\
12. & Pinus Elok & 3.527 .000 \\
13. & Pondok Bambu & 4.973 .000 \\
14. & Pulau Gebang & 4.117 .000 \\
15. & Pulo Jahe & 6.147 .000 \\
16. & Rawabebek & 3.046 .000 \\
17. & Tambora & 5.507 .000 \\
18. & Tipar Cakung & 4.307 .000 \\
19. & Cipinang Besar Utara & 6.600 .000 \\
20. & Cipinang Muara & 6.677 .000 \\
21. & Semper & 3.895 .000 \\
22. & Kapuk Muara & 4.868 .000 \\
\hline
\end{tabular}

Data Source: DKI Jakarta Public Housing and Settlement Area Agency, 2020

Seen in table 3. The above shows that the average income of the people living in the flats ranges from Rp. 3,000,000 - Rp. 6,000,000. Residents who live in Rawabebek flats have the lowest average income compared to other flats in DKI Jakarta, with an average income of around Rp. 3,045,000. With an income of around three million rupiah, of course, residents will find it very difficult to meet the needs of daily life, which they have to incur additional costs compared to when they were in their home areas which did not incur costs, such as the need for clean water, rental flats, higher electricity rates. Compared to the area of origin, transportation costs to work are relatively high. Housewives who previously could help their husbands to find additional income by opening a shop or trading, when they moved to the condominium they automatically did not get additional income to meet the needs of their family due to the quiet conditions of the flats during the pandemic (Tuti, 2017)

The residents who are relocated are generally low-middle income people, where they have jobs that are very dependent on the location where they live, such as fishermen who live close to the beach, construction workers and coolies who are dependent on the market. The relocation certainly has an impact on their lives which are different from the situation and conditions when they were in their original place of 
residenc (Tuti, 2017)

With the economic conditions slumped during the COVID-19 pandemic, while apart from meeting basic needs, they also had to spend additional expenses. such as: rent for flats of around 300 thousand per month, need for clean water (PDAM), electricity tariffs that are higher than in the area of origin, drinking water needs because PDAM water is not suitable for drinking, transportation costs to work locations are due to transportation facilities previously prepared by the government DKI Jakarta province in the form of buses, since the COVID-19 pandemic, the mode of transportation for residents of flats has been stopped. There are elements that residents complain about, namely: payment of flats for rent, during the COVID-19 pandemic they should have received subsidies from the government or delayed payments, but this was not implemented. The community's economy cannot develop due to the following factors: the remote location of the flats; the manager of the Rawabebek rusunawa management unit (UPRS) is less innovative in empowering the residents (IMF, 2020). There are 3 key factors that need to be considered in empowering, namely: Strategy, Resources and public accountability (Elliott et al., 2019).

Rusunawa Rawabebek DKI Jakarta basically in terms of area has very potential prospects to be developed. There is land behind the rusunawa area which has the potential for livestock or agricultural land. The land is very promising for agricultural development such as vegetable crops, catfish or poultry farming. The roof area of the flats is also very potential for the development of hydroponic plants. Currently, the Rawabebek rusunawa area has an area of 1000 square meters which has been developed as a chili plantation area. Chili plants whose seeds come from the assistance of the Directorate General of Horticulture, Ministry of Agriculture of the Republic of Indonesia. This was revealed during monitoring from the DKI Jakarta Food, Maritime and Agriculture Security Service (KPKP) and the Agricultural Technology Study Center (BPTP). The farmer groups (Poktan) in the Rusunawa had previously been given technical guidance (Bimtek) for the cultivation of double-fold chili production (Proliga), in collaboration with DKI Jakarta .

"We really appreciate the persistence of the residents of Rawa Bebek Rusunawa who are passionate about cultivating this land so that it is ready to be planted with chili. Come on, we invite other residents of the flats to participate in agricultural cultivation activities, both conventionally and hydroponically. This vegetable crop has great potential to increase the 
income of local residents and maintain food security, especially the residents of the Rawa Duck Rusunawa," said Asih Sumaretmi. Poktan Rusunawa Rawa Bebek also has a set of hydroponic equipment units, for planting pakchoy, kale, and spinach, which the local residents are very interested in. "Once a month they are able to harvest the various vegetables, buyers already exist, namely mothers who live in this Rusunawa," added Asih".

Land use in Rawabebek flats basically has the potential to increase food security in DKI Jakarta. The above is a form of collaboration between the ministry of agriculture and the provincial government of DKI Jakarta in utilizing vacant land foractivities urban farming. The position of the rusunawa which is on the flood bank of the east canal is also very potential in developing water tourism and opening culinary businesses on the edge of the canal, but this has not yet been developed. Collaboration in empowering residents of Rawabebek flats does not only involve the government, but is also carried out with thesector private, academics and non-governmental organizations, as shown in the following programs:

1. Batik training for women who live in flats in collaboration with UPRS and the women of the National Crafts Council. (deskranada)

2. Sewing training for mothers in the flats, collaboration between UPRS and Small and Medium Enterprises (UMKM LItle Baby) and Non-Governmental Organizations The Indonesian Concern Movement (GKI).

3. Training and assistance in waste bank management, collaboration between UPRS with universities and the Indonesian Concern Movement NGO.

However, from several collaborations carried out in empowering the relocation community at the Rawabebek flats above, it has not shown good results, especially during the current covid 19 pandemic. The economic life of the people is getting worse. This can be seen from the high rent arrears of the residents and the number of unemployed residents. According to Asih Sumaretni (Head of UPRS) Rawabebek, as many as 90 percent or 640 families, have not paid the arrears of the flats. The length of arrears is generally 10-20 months. Many of the inhabitants are unemployed and working odd jobs so unable to meet their daily needs and pay a flat fee. (Interview with head UPRS rusunawa Rawabebek, January 2021)

Collaborative governance needs to be done as an effort to overcome poverty problems (Zhang et al., 2020). The results of the study indicate that the collaboration process in empowerment that has been carried out so far for the relocation community in Rawabebek 
flats has only touched the instrumental aspect and has not touched the substantial aspect. The instrumental aspect in question is that the collaboration process is carried out without looking at the real conditions of the potential that exists in the community, both in terms of interests/talents, skills possessed by the community and the potential use of the environment where the community is located. Several programs from the collaboration carried out by UPRS with thesector private, NGOs, academics, such as training in batik, sewing, experienced obstacles in the marketing process so that community production piled up which eventually resulted in losses. Likewise, the management of waste banks is experiencing obstacles in terms of sorting and collecting waste and urban farming, where after the formation of groups in the community, intensive assistance is not carried out so that the results are not optimal and have no significant effect on improving the economic life of the community. Communities who live in flats who have a coastal community background accompanied by a low level of education of course need intensive assistance in implementing the programs they are just starting out with compared to when they were in their home areas, which depended more on economic activities that were not organized (informal). . This can be seen in the data of several collaboration empowerment programs between several stakeholders below:

Table 4.

The Role of Stakeholders in Collaboration for Community Empowerment Relocation of Rusunawa Rawabebek

\begin{tabular}{clllc}
\hline No. & Type of Program & $\begin{array}{c}\text { Stakeholders } \\
\text { involved }\end{array}$ & $\begin{array}{c}\text { Role of } \\
\text { Stakeholders }\end{array}$ & $\begin{array}{c}\text { Participation } \\
\text { Community }\end{array}$ \\
\hline 1. & Urban Farming & Government & $\begin{array}{l}\text { Facilitator } \\
\text { Monitoring } \\
\text { evaluation }\end{array}$ & High \\
2. & Waste Bank & NGO, Academic & $\begin{array}{l}\text { Training, } \\
\text { Mentoring }\end{array}$ & High \\
3. & sewing & Private, NGO & training & Low \\
4. & batik & Private, NGO & training & Low \\
\hline
\end{tabular}

Data source : UPRS Rusunawa Rawabebek DKI Jakarta 2021

The table above shows that community participation in the sewing and batik program is low because the program does not match the interests of the community. Then there is no 
intensive assistance to the production and marketing process. At the beginning of the collaboration process, the community should be involved in the formulation of the program that will be realized, the program should be in accordance with their interests, potential and the environment that supports the program. While on the other hand the relocation community basically has great potential to be empowered and actively involved in the collaboration process based on kinship values because they come from the same community (same area of origin) and togetherness values because they share the same fate (both victims). eviction). Strengthening the values of togetherness in a network of community groups without barriers and boundaries will be more effective in uniting various different interests for theinterest of commonovercoming the COVID-19 pandemic. The network formed will build collective solidarity. States that a set of informal values or norms that are shared among members of a group will enable good cooperation between them (Fukuyama, 2014). The collaborative process in empowering relocation communities should be based on social capital. Social Capital has important potential in empowering the community, especially those affected by the COVID-19 pandemic.capital Socialis capital that can be used as the driving force in empowerment. Social capital provides support to the community to take action together and reciprocally obtained. Social capital is an alternative form of modality that is beneficial for the community to obtain both economic and social benefits. Social capital has a synergy with the principles in the sustainable inclusive development paradigm. Development or policies affiliated with community social capital can be implemented in a moremanner bottom-up because it focuses on the community not only as an object, but also as a subject of development itself.

\section{Conclusion}

Based on the results of the research described above, it can be concluded that the collaborative process in empowering the relocation community in Rawabebek flats has only touched the instrumental aspect and has not touched the substantial aspect. The collaborative process in empowering relocation communities should be based on social capital. This is based on the fact that the relocation community basically has great potential to be empowered and actively involved in the collaborative process based on kinship values because they come from the same community (same area of origin) and togetherness values because they share 
the same fate (same as victims). eviction). capital Socialis capital that can be used as a driving force in empowerment. Social capital provides support to the community to take action together and reciprocally which is obtained. Social capital is an alternative form of modality that is beneficial for the community to obtain both economic and social benefits.

\section{References}

\section{Books}

Fukuyama, Francis. (2014).The Great Disruption: Hakikat Manusia dan Rekonstitusi Tatanan Sosial, Yogyakarta: Penerbit Qalam. (terjemahan).

Huraerah, Abu. (2011). Pengorganisasian dan Pengembangan Masyarakat: Model dan Strategi Pembangunan Berbasis Kerakyatan, Edisi Kedua. Bandung: Humaniora

\section{Journal article}

Baker, Bloom, \& Davis. (2020). COVID-induced economic uncertainty and its consequences I VOX, CEPR Policy Portal. 1-8.

Citra, Permana Arif.,Sasmito, Cahyo., Gunawan Cakti, Indra. (2018). Implementasi Pemberdayaan Masyarakat Dalam Program Keluarga Harapan Untuk Memutus Mata Rantai kemiskinan di Kota Malang. Jurnal Politik dan Sosial Kemasyarakatan. Vol.10 No.2.

Enciso, Martha., Santocildes , Ana, Lidu.,Laura Gomes. (2019). Drivers for a cross-sector successful collaboration: The Basque country model of action.International.

Fhatoni, Ahmad, (2020). Dampak covid 19 dan Kebijakan PSBB Pemerintah terhadap UMKM di Wiyung Surabaya. Oleh Ahmad Fhatoni. Jurnal Prodi Ekonomi Syariah, Vo.3 No.1.

Ristyawati, Aprista, (2020). Efektifitas Kebijakan Pembatasan Sosial Berskala Besar (PSBB) dalam Masa Pandemi Covid 19 Oleh Pemerintah sesuai Amanat UUD 1945. Administrative Law and Governance Journal, Vo.3 No.2.

Rhodes, R. A. W. (1996). The New Governance: Governing without Government. Political Studies, XLIV, 652-667.

Sonderskov, Mette. (2019). Do local politicians really want collaborative governance? International Journal of Public Sector Management, Vol. 32 No. 3, pp. 320-330

Tuti, Retnowati, (2017). Kondisi Eksisting Tahun 2016 Pelayanan Rusunawa Rawabebek DKI Jakarta. Swatantra, volume 15 No.1. 
Zhang, Na., Zhang, XiangXiang., Lei, Ming, Yang, Yingie. (2020). Multiagent Collaborative Governance for Targeted Poverty Alleviation from the Perspective of Stakeholder. Hindawi Complexity, Volume 1 No.1 . Article ID 8276392.

\section{Journal article with DOI}

Aduhene, Tanoh, David.,\& Osei Assibery, Eric. (2020). Socio-economic impact of COVID-19 on Ghana's economy: challenges and prospects. International Journal of Social Economics. DOI 10.1108/IJSE-08-2020-0582.

Emerson, K., Nabatchi, T., \& Balogh, S. (2012). An integrative framework for collaborative governance. Journal of Public Administration Research and Theory, 22(1), 1-29. https://doi.org/10.1093/jopart/mur011.

Elliot, Ian Charles., Violetta Fejszes \& Mariola Tarrega. (2019). The Community Empowerment Act and localism under devolution in Scotland .The perspective of multiple stakeholders in a council ward. Vol. 32 No. 3, pp. 302-319.DOI 10.1108/IJPSM-032018-0080.

Eweje, Gabriel., Aymen Sajjad. (2020). Multi-stakeholder partnerships: a catalyst to achieve sustainable development goal. Marketing Intelligence and planning journal, Vo.15 No.4. DOI 10.1108/MIP-04-2020-0135

Frankowski. Andrea (2019). Colabotrative governance as a policy strategi in healtycare. Jounal of helath organization and management, Volume. 3 DOI 10.1108/JHOM-10-2018-0313.

Larruina, Robert., Kees Boersma., Elena, Ponzon. (2019). Responding to the Dutch Asylum Crisis: Implications for Collaborative Work between Civil Society and Governmental Organizations . Social Inclusion. Vol. 7, Issue 2, pp. 53-63. DOI: 10.17645/si.v7i2.1954.

Maria, Fernanda Diaz., Delgado . (2019). Detonating factors of collaborative innovation from the human capital management. Journal of Enterprising Communities people and places in the global economy, Vol.14 No.1 pp.145-160. DOI 10.1108/JEC-10-2019-0102.

Mutonyi, Barbara Rebecca, Terje Slatten\& Lien, Gudrand Lien. (2020). Empowering leadership, work group cohesiveness, individual learning orientation and individual innovative behaviour in the public sector: empirical evidence.International Journal of public leadership . Vo.16 No.2 pp.175-197. DOI 10.1108/IJPL-07-2019-0045. 
Ntale, Peter. (2020). Interagency collaboration for graduate employment opportunities in Uganda Gaps in the structure of organizations.Education and training. Vo.62 No.3 pp.271-291. DOI 10.1108/ET-08-2019-0193.

Ozili. Peterson. (2020). Covid 19 in Africa:socio-economic impact, policy response and opportunities. International Journal of Sociology and Social Policy. DOI 10.1108/IJSSP-052020-0171.

Udin, Nasir. (2019). Empowerment through participation in local governance: the case of Union Parishad in Bangladesh. Public Administration and Policy. Vol. 22 No. 1.pp. 4054.DOI 10.1108/PAP-10-2018-0002.

\section{Newspaper article}

IMF. (2020). FISCAL MONITOR : Policies to Support People During teh COVID-19 Pandemic. International Monetary Fund (IMF). 